\title{
CRIMINAL JUSTICE SYSTEM IN ERADICATION OF CORRUPTION IN INDONESIA
}

\author{
Bambang Dwi Baskoro, Hartiwiningsih, Hari Purwadi \\ Doctoral Programme of Faculty of Law UNS Surakarta, bambangdwibaskoro@gmail.com \\ Faculty of Law UNS Surakarta, hartiwi50@yahoo.com \\ Faculty of Law UNS Surakarta, hpurwadie@gmail.com
}

\begin{abstract}
Criminal Justice System in eradication corruption is spesialisation in around General Trial, not yet the same as Usually Criminal Justice System. It's not integrated like normal criminal justice system, because each other institution work in criminal justice system itself so appearance the fragmentaris and egosectoral. The regulating in Law is criminal justice systemsin eradication corruption emplaced Corruption Eradication Commission (KPK) as coordinator, supervision, trigger mechanism institution besides as investigators and prosecutor corruption.
\end{abstract}

Keywords:criminal justice system-KPK-crimes against corruption.

\section{Introduction}

The effort eradiction corruption is not easy. This is because of corruption more complex, caused corruption be entrenched in various level of society. ${ }^{1}$

Criminal justice system is a system that found in society for eradication of crimes. System approach in eradication of crimes is correct for eradication of crimes that will done in boxes that seems egosectoral. It still found the fragmentaris in sub-subsystems signalized by Sudarto since in the year 1977 that says, if seem inside of Law Regulating, castle centris and fragmentaris that appointment not unity in diversity.

Base on that regulating in Law Number 30 Year 2002 on Crimes Against of Corruption Eradication Commission and Law Number 46 Year 2009 on Trial of Crimes Against Corruption, then includes two criminal justice systems in Indonesia, mentioned:

1. Criminal Justice System in normal situation (based on constitutional law in normal situation); and

2. Criminal Justice System in extra ordinary situation (based on constitutional law in emergency situation).

Arrive on Corruption Eradication Commission (KPK) as law enforcement institution is inconstitusional, that increase because the State in Emergency in Era Pra Reformation. Such as we know, that the commitment nation's about declaration of the Indonesian people's

\footnotetext{
${ }^{1}$ Hibnu Nugroho, "Efektivitas Fungsi Koordinasi dan Supervisi dalam Penyidikan Tindak Pidana Korupsi oleh Komisi Pemberantasan Korupsi”, Jurnal Dinamika Hukum, Vol 13 No. 3, (September 2013): 392.
} 
determination to eradicate corruption in the TapMPR RI No.XI/MPR RI/1998 on the Clean and Free State Administration from Corruption, Collution and Nepotisme. Even the fact is arrive this institution seems like eye sides by other institutions that Yonki Karman says the much politician and state officials that corrupt which it feels threatened by Corruption Eradication Commission (KPK) as law enforcement institution that hardly controlled by politics power.

Even, in the arranged journey to now happened some effort to weakness Crruption Eradication Commission (KPK) in eradication corruption, such as :

1. Criminalization on the chairman of Corruption Eradication Commissiom until they are nonaktif in position such as criminalization on Antasari Azhar, Bibit Samad Rianto and Chandra M. Hamzah (second periode in 2007-2011) as well as Abraham Samad and Banbang Widjojanto(third periode in 2011-2015).

2. Judicial review on Law Number 30 Year 2002 on Corruption Eradication Commission (KPK) recorded in history there are 13 times submission of written statement on Republic of Indonesian Constitutional Court.

3. Revition of Law Regulating since Bill in Parliament-Code of Criminal Law and so on purpose to restriction opportunity of Corruption Eradication Commission (KPK) on tapping, prosecute the case, limit range of work Corruption Eradication Commission (KPK) on 12 years and case corruption under 5 miliar not handle on Corruption Eradication Commission (KPK).

4. Pull of investigator officials by Police, and so on.

The problem that show of this paper is : (1).Factors caused the criminal justice system still hardly to eradicate corruption? and (2).How should be the criminal justice system organized?

\section{Discussion}

\subsection{Factors are caused of criminal justice system still hardly to eradicatecorruption}

There are four strategy of to eradicastion corruption: focus on law enforcement, condemnation against the perpetrator, community engagement,in preventing and detect corruption, as weel as an attempt to undertake these reforms in public sector. ${ }^{2}$

\footnotetext{
${ }^{2}$ Teguh Kurniawan, "Peranan Akuntabilitas Publik dan Partisipasi masyarakat dalam Pemvberantasan Korupsi di Pemerintahan", Bisnis dan birokrasi, Jurnal Ilmu administrasi dan Organisasi, Volume 16 No II, (Mei-Agustus 2009): 119-120.
} 
In Criminal Justice System in emergency situation increased there is Crimes Against Corruption's Court with Corruption Eradication Commission (KPK) Institution as : investigator and so public prosecutor, coordinator dan supervisor, trigger mechanism institusion and grand designer institution. Corruption Eradication Commission (KPK) is not implementation if Police Institution and Public Prosecutor Institution work on their job optimally, although two institutions not yet work efektiffically and optimally needed new institution that unpermanently or ad hoc. Eradication of crimes against corruption by Coruption Eradication Commission (KPK) become strong foundation for economic growth to the future, because that eradication of crimes is essensial corruption that is political corruption.

Political Corruption is politicians that emposition in executive or legislative power used the power to interested to body itself and the their group. Arnold Heidenheimer and Michael Johnston as says M. Fajar Marta, political corruption is corruption that handled by politician actors/actrees in executive or legislative power usually his power to itself ' $\mathrm{s}$ interested and group of political's interested. Political corruption in Indonesia relationship with patronage democracy that relationship between some person who hold the position on politic/business that give the some fund to public officials for their opportunities and his relationship for win the public project's tender for himself. Not surprised if beginning the reformation until now, there is 8 minister, 2 Governor of Bank Indonesia, 18 Governor, 1 General with Four Star and 3 General with Three Star, 40 member of Legislative Institution, and 200 Head of Region Stage II/Head of Citizen imprisoned.

What we must bear in mind is politics are to be adopted to the laws, and not the law to the politics. Then, as we know that Denny Indrayana says that the Political support is not necessarily positive, particulary because political parties are still part of the problemand not the solution-for anticorruption efforts. To make the situation worse, the parties are usually closely linked with corrupt businessmen who support them financially. This financial support means the parties lack independence and are easily contaminated by corrupt practices and vested interests. Such we know criminalization on the chairman of Corruption Eradication Commission until they are nonaktif in position is criminalization's effort conducted by another law enforcement such as criminalization on Antasari Azhar, Bibit Samad Rianto and Chandra M. Hamzah (second periode in 2007-2011) as well as Abraham Samad and Banbang Widjojanto (third periode in 2011-2015) Even President R.I. on the age of leadership arrange this finally made of public statement that the case against 
the commissioners should be settled 'out of the court', meaning no legal prosecution shoud be carried out against them.

According to Article 6 section c jo Article 11 Law Number 30 Year 2002 and General Elucidation of Law Number 30 Year 2002, Corruption Eradication Commission is authorized to conduct investigations and prosecutions of corruption which

1. involves law enforcement officers, state officials and other persons connected withcorruption acts committed by law enforcement officers or state administrators;

2. gaining attention that disturbs society; and/or

3. concerning state losses of at leastRp.1.000.000.000,00 (one billion rupiahs). According this statement, at the first, Corruption Eradication Commission is authorized to conduct investigations and prosecutions of corruption which involves law enforcement officers or state officials.

In addition, other persons connected with corruption acts committed by law enforcement officers or state administrators. Other persons connected with corruption acts committed by law enforcement officers or state administrators is usually an political actors or businessmen.

Based on data perception corruption of index, Indonesia still includes the Corruption Nations. According the survey of International Transparency Indonesia reach the score 3 passed by 0,2 from score one year ago, Indonesia includes the range of- 100 from 183 Country/Nation. Base on the corruption situation in the 117 Country/Nation in Year 2013 that closed by International Transparency, Indonesia on the position 64 Country/Nation best of corrupted nation (Indonesia in position 60 Corrupt Country/Nation in the last year). According to Teten Masduki, for reach needed reform licensi regulating and reform law enforcement apparatus for whole. According to Susilo Bambang Yodhoyono, Indonesia need time 45 year for free from corruption.

Based on data that the cases which handle by Corruption Eradication Commission (KPK) since 2006:

TABEL I

THE CASES WHICH HANDLE BY KPK SINCE 2006

\begin{tabular}{llllllllll}
\hline Tahun & 2006 & 2007 & 2008 & 2009 & 2010 & 2011 & 2012 & 2013 & 2014 \\
\hline Inquiry & 36 & 70 & 70 & 67 & 54 & 78 & 77 & 81 & 80 \\
Investigation & 27 & 24 & 47 & 37 & 40 & 39 & 48 & 70 & 58 \\
\hline
\end{tabular}




\begin{tabular}{llllllllll}
\hline Prosecution & 23 & 19 & 35 & 32 & 32 & 40 & 36 & 41 & 45 \\
"Inkracht" & 17 & 23 & 23 & 39 & 34 & 34 & 28 & 40 & 40 \\
Ececution & 13 & 23 & 24 & 37 & 36 & 34 & 32 & 44 & 48 \\
\hline
\end{tabular}

Data is taken over from Newspaper: Kompas, (Thursday 22 January 2015):1-15.

According to Denny Indrayana, several reasons why KPK is given the mandate to focus to eradicate political corruption and justice: (1) .KPK is relatively cleaner than other law enforcements, and (2) .KPK is an independent state commission, unlike the Attorney and Police under the supervision of the President. ${ }^{3}$ Ahmad Syafii Maarif in the "Preface" book written by Denny Indrayana states, that Without the eradication of corruption, all the reform efforts towards a democratic Indonesian state is impossible. The country that holds the title of champion of corruption will never become a democratic country. If this corruption eradication movement fails then the more perfect the failure of Indonesiannation to create a corruption-free countryfails. ${ }^{4}$ Relation that, there is person the name John Emerich Edward Dalberg Acton (Lord Acton) in privacy letter send to Mandell Creighton say that power tends to corrupt and absolute power corrupts absolutely. ${ }^{5}$

Pull of Investigator according to Article 6 sub c Law Number 30 Year 2002, Corruption Eradication Commission is investigator and public prosecution in corruption cases. Corruption Eradication Commission (KPK) recruit person experience from Police Institution, Public Prosecutor Institution, BPK, and PPATK as investigator. Although, Corruption Eradication Commission (KPK) recruit person experience from Public Prosecutor Institution. Corruption Eradication Commission (KPK)not recruit person from the outside investigator and public prosecutor as well as train to skill himself.

Relation with a pull of investigator by Police Departement, according Article 5 section (3) Government Regulating Number 63 Year 2005 on Human Resources Managemen System on Corruption Eradication Commissionsaid thatage of workofASN that employee on Corruption Eradication Commissionrange in 4 years and can only long in ones again. ${ }^{6}$ Febri Diansyahsays that pull investigator by Police Departement before person itself for 4years can broke rule regulating and broke the law.Law Regulating with this to prevent potential interventie to Corruption Eradication Commission. Although, employee that work on this

\footnotetext{
${ }^{3}$ Denny Indrayana. Negeri Para Mafioso, Hukum di Sarang Koruptor. (Jakarta, Penerbit Kompas, 2008), 75.

${ }^{4}$ Ibid., xi.

${ }^{5}$ http://www.kompas.com ( 8 November 2015): 5.

${ }^{6}$ http://www.kompas.com Donald Fariz, "Defisit Penyidik KPK”,( 27 September 2012): 7.

Defisit investigator skilled caused KPK suggest inisiatif investigator from out of Police Departement and Public Prosecutor (Kompas, Thursday, 2012 September 27, page 7 and Media Indonesia, Thursday, 2015 Mei 28), page 1.
} 
situation is work main job as investigator or public prosecutor. For that according Article 39 Law Number 30 Year 2002 on Crimes Against Corruption Eradication Commission statement that investigator and public prosecutor become employee in Corruption Eradication Commission to stopped temporarily from Police Departement and Public Prosecutor Institution as long as become employee Corruption Eradication Commission.

According to General Elucidation of Law Number 30 Year 2002 on Crimes Against Corruption Commission, Corruption Eradication Commission (KPK) become a trigger mechanism institution against existing institutions in eradication of corruption without monopolizing the duties and authorities of investigation and prosecution. That means, to be a counter partner conducive to existing institutions so that the eradication of corruption can be carried out efficiently and effectively. Although that, Corruption Eradication Commission (KPK) take of facilities and financials which better than other institutions such as Police Department or Public Prosecutor Department. There is a jealously in this situation from another law enforcement of succeed activity of Corruption Eradication Commission (KPK) it caused get the better facility and better financial until their activity is very best.

Corruption Eradication Commission (KPK) can do activity of investigator and public prosecutor besides opportunity of Police Department and opportunity of public prosecutor, because as trigger mechanism foractivity such like Corruption Eradication Commission (KPK).Based on survey that handle by Indo Barometer on date 14th-22thSeptemberin 2015 on the 34 provincy in Indonesia with 1.200 respondents, Corruption Eradication Commission (KPK) is institution with the level public believablein position very highlevel that is score $82 \%$, continuedIndonesia National Force with the score $81 \%$,continued with the President with score $78,6 \%$. Among apparatus law enforcement, public satisfaction on activity Corruption Eradication Commission score68,2\%, continued Police Department score 44,8\%, Judges Department range 40,7\% and Public Prosecutor Institution range 37,7\% as well as Lawyer range 27,2\%. Government need the Corruption Eradication Commission, it caused the work very clean and believable institution. ${ }^{7}$

According to Article 6 section a juncto Article 7 and 42 and General Elucidationof Law Number 30 Year 2002 on Crimes Against Corruption of Eradication Commission,Corruption Eradication Commisssion (KPK) is coordinate with agencies authorizedto eradicate corruption, for which is authorized to coordinate investigation and prosecutionof corruption, and so on. Then, according toArticle 6 section b juncto Article 8

\footnotetext{
${ }^{7}$ http://www.kompas.com ( 9 Oktober 2015): 1.
} 
LawNumber 30 Year 2002, to supervise the agencies authorized to eradicate corruption, forwhich is authorized to take over the investigation or prosecution of perpetrators of corruption perpetrated by Police Department or Public Prosecutor Department (see Article 9 juncto Article 10 Law Number 30 Year 2002). Then, according to General Elucidation of Law Number 30 Year 2002, Corruption Eradication Commisssion (KPK) builds the law enforcement's networking in efforts to eradicatecorruption and to design and encourage the implementation of socialization programsto eradicate corruption.

In view of Article 6.7, 8, 9, 10, 11, 13, 14 and Article 42 and related articles, the KPK is designated and arranged a network of activities against corruption; triggers mechanism and empowerment; coordinating agencies; and institutions that supervise, it can be said indirectly forming act putthe KPK as Top Leader in Criminal Justice Systems of Eradication Corruption. Even according to the Law, the KPK is placed as the supervisor of the Supreme Administrator. However, it is unfortunate that this provision is ignored by other law enforcement agencies, since the KPK is a non permanent institution and is not regulated in the 1945 Constitution. . This is because in the state of Indonesian law, the development of the national legal system based on the Constitution of the Republic of Indonesia Year $1945 .^{8}$ It means the Corruption Eradication Commission (KPK) emplaced in position a leader even topof leader of Criminal Justice System in Eradication Crimes Against Corruption, even other institution not agree this argument because not permanently position or ad hoc institution.

Coordination and Supervision is two of manager's function/leader's function as say Stephen P. Robbins and Timothy A. Judge in 'Organizational Behavior'. That function is a Planning, Organizing, Leadership and Controlling the Human Resources, that in the organization.Grand design relates with Planning Function, coordination relates with Organizing Function and supervision relates with Controlling Function. ${ }^{9}$

Relationship that argument,criminal justice system as organize is a big-big organize because mentioned sub-sub system as organize too. Organize need a leader as manager that planning, organizing, controlling and leadership as activity. Planning relation with job description Corruption Eradication Commission (KPK) as grand design. Grand design to a nation (Indonesia) to prevention and eradication of crimes against corruption, to design/build a network

\footnotetext{
${ }^{8}$ Retno Saraswati, "The Function of Ideal Law in Preparation Regulation Legislation in order to Creating Eqitable Regional Development," Diponegoro Law Review, Volume 02, Number 01, (April 2017): 117

${ }^{9}$ Stephen P. Robbins and Timothy A. Judge, Organizational Behavior, (Pearson Education Inc., New Jersey, USA, 2015), 2-3.
} 
in state institutions for reach the Clean and Free Corruption, Collussion, Nepotisme Government's.

\subsection{The Ideal of Organized Criminal Justice System}

Criminal justice system in eradication of corruption or criminal justice system in abnormal's situation : Police Department, District Public Prosecutor and Corruption Eradication Commission (KPK) can held the corruption's cases from Investigation Stage I or II, than Corruption Eradication Commission (KPK) can carry on the Police Department or District Public Prosecutorin Investigation Stage II and then Police Deprtment or District Public Prosecutor carry into Prosecution's Stage. Then, public prosecution from OfficialCoruption Eradication Commission(KPK) or Official District Public Prosecutor delivery to Crimes Against Corruption's Court inhis region itself for the vonnis. For those as the Picture 2 explained :

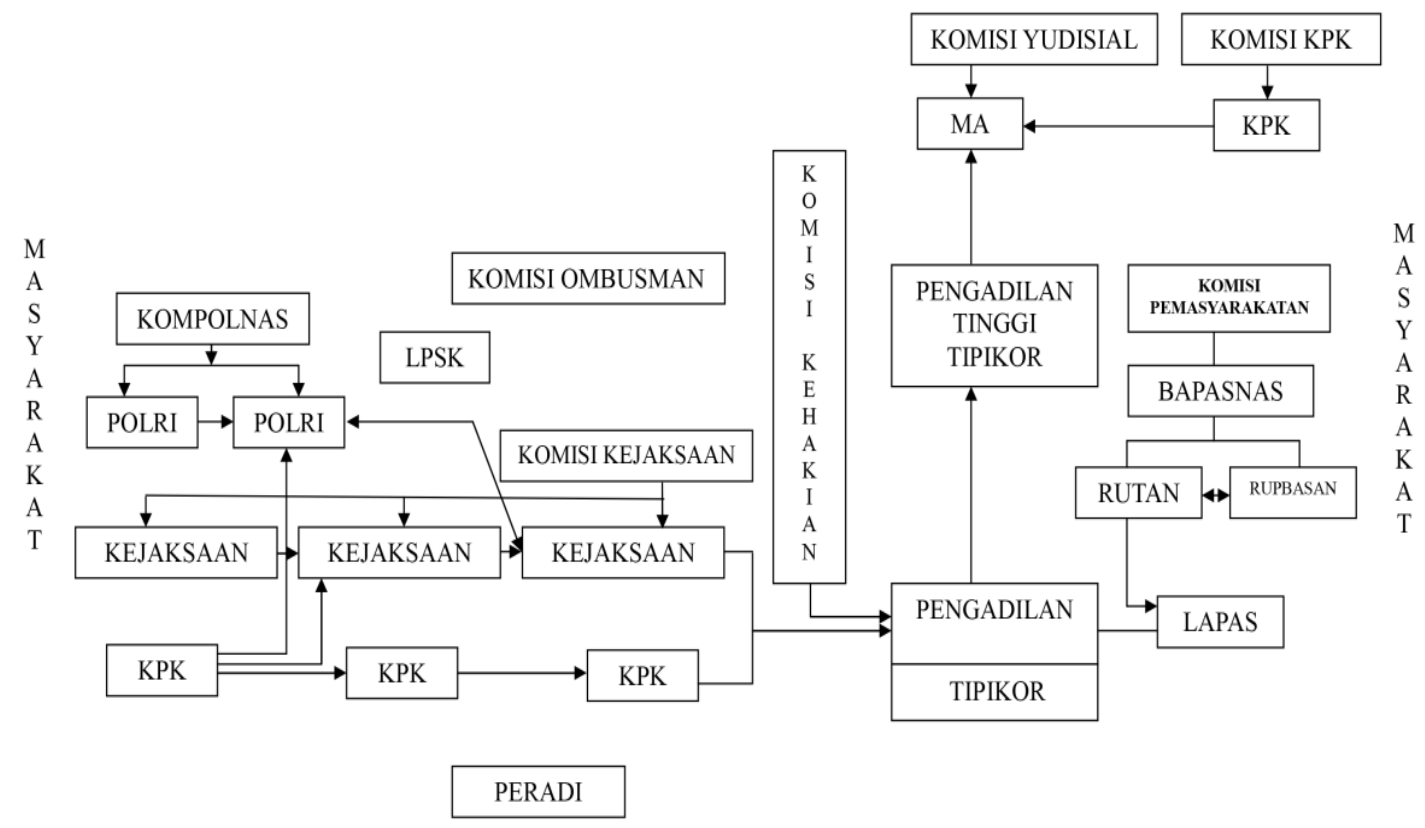

In this picture entry criminal justice system is from the people and goal of criminal justice system is resocializedto people again. There is external supervisor like Kompolnas for Police Department, Komisi Kejaksaan for Public Prosecutor, and Judges's Commission for The Court's and Commission on KPK as well as Yudicial Commission for all of criminal justice system as well as Resocialized Commission for Bapasnas. Bapasnas includes the Lapas, Rutan and Rupbasan. 
Investigation can hold the Corruption Eradication Commission is very effective and efficiency, until Corruption Eradication Commission as leader in eradication of crimes against corruption is reasonable. Crimesagainst corruption is extra ordinary crimesthat handle with extra ordinary institution by extra ordinary efforts too.This institutionunpermanently/temporarely. Soon, if crimes against corruption have been pressured minimalized maybe opportunity back to prequel institutions such as Police Department.

\section{Conclusions}

Factors are caused of criminal justice system still hardly to eradicate corruptionis politicians that emposition in executive or legislative power used the power to interested to body itself and the their group and not function of coordinator, supervisor and trigger mechanism Corruption Eradication Commission (KPK) optimalized. Corruption Eradication Commission (KPK) emerged as an institution to prevent and eradicate criminal acts independent corruption by involving the active participation of the community at in efforts to prevent and eradicate corruption. The goal of national strategy in the prevention and eradication of criminal acts of corrupture is forming a special law enforcement network to prevent and eradicate corruption in which the Corruption Eradicate Commission (KPK).

Corruption Eradication Commission (KPK) is placed as: coordinator, supervisor, grand designer, trigger mechanism institution, even become the top leader of law enforcement for prevention and against all corruption activities. That means, criminal justice system seems like organized is very important until he must organized like organization which handle a top leader who applied planning, organizing, leadership, and controlling of human resources. Controlling with internal supervisor and external supervisor is very important.

\section{References}

Http://www.kompas.com Fariz, Donald. (2012). Defisit Penyidik KPK.

Nugroho, Hibnu. (2013). Efektivitas Fungsi Koordinasi dan Supervisi dalam Penyidikan Tindak Pidana Korupsi oleh Komisi Pemberantasan Korupsi, Jurnal Dinamika Hukum, Vol 13 No. 3.

Indrayana,Denny. (2008). Negeri Para Mafioso, Hukum di Sarang Koruptor. Jakarta: Kompas.

Http://www.kompas.com ( 9 Oktober 2015).

Http://www.kompas.com ( 8 November 2015). 
Sarawati, Retno. (2017). The Function of Ideal Law in Preparation Regulation Legislation in order to Creating Eqitable Regional Development. Diponegoro Law Review, Volume 02, Number 01, 117.

Kurniawan, Teguh. (2009). Peranan Akuntabilitas Publik dan Partisipasi masyarakat dalam Pemberantasan Korupsi di Pemerintahan. Bisnis dan birokrasi, Jurnal Ilmu administrasi dan Organisasi, Volume 16 No II, 119-120.

P. Robbins, Stephen and Timothy A. Judge. (2015). Organizational Behavior, Pearson Education Inc., New Jersey, USA. 